\title{
Exotic trees contribute to urban forest diversity and ecosystem services in inner-city Cleveland, $\mathrm{OH}$
}

\author{
Christopher B. Riley, Daniel A. Herms, and Mary M. Gardiner \\ Department of Entomology \\ The Ohio State University
}

\begin{abstract}
Vacant land, a product of population and economic decline resulting in abandonment of infrastructure, has increased substantially in shrinking cities around the world. In Cleveland, Ohio, vacant lots are minimally managed, concentrated within low-income neighborhoods, and support a large proportion of the city's urban forest. We quantified abundance, richness, diversity, and size class of native and exotic tree species on inner-city vacant lots, inner-city residential lots, and suburban residential lots, and used i-Tree Eco to model the quantity and economic value of regulating ecosystem services provided by their respective forest assemblages. Inner-city vacant lots supported three times as many trees, more exotic than native trees, and greater tree diversity than inner-city and suburban residential lots, with the plurality of trees being naturally-regenerated saplings. The urban forest on inner-city vacant lots also had two times as much leaf area and leaf biomass, and more tree canopy cover. The quantity and monetary value of ecosystem services provided by the urban forest was greatest on inner-city vacant lots, with exotic species contributing most of that value, while native taxa provided more monetary value on residential lots. The predominately naturally-regenerated, minimally managed exotic species on vacant land provide valuable ecosystem services to inner-city neighborhoods of Cleveland, $\mathrm{OH}$.
\end{abstract}


Keywords: Green infrastructure, green space, i-Tree Eco, invasive species, urban forest assessment, vacant land

\section{Introduction}

Urban populations are expected to grow by 2.5 billion people over the next several decades and account for close to two-thirds of the global population (Floater et al. 2014). Although urbanization is a dominant landscape pattern on a global scale (Grimm et al. 2008), many cities are currently experiencing population and economic decline (Blanco et al. 2009). The term 'shrinking city' has been used to define "an urban area...that has experienced population loss, economic downturn, employment decline, and social problems as symptoms of a structural crisis" (Martinez-Fernandez et al. 2012). As cities shrink, infrastructure is abandoned and vacant land increases predominately within the city core (Kremer et al. 2013), creating a multitude of challenges for policymakers, urban planners, businesses, and residents (Bonham et al. 2002, Alexander 2005).

In the absence of population growth, vacant lots tend to persist as minimally managed parcels of land that can lower the value of adjacent properties, depress tax revenue, and deter community revitalization (Rybczynski and Linneman 1999, Pagano and Bowman 2004, Alexander 2005). These parcels are often concentrated within low-income, inner-city neighborhoods (Accordino and Johnson 2000) where access to green space is often limited (Wolch et al. 2014). Despite the existing challenges associated with vacant land, it presents an opportunity for the establishment of pockets of urban wilderness and other green spaces that can improve environmental quality by supporting biodiversity and provisioning ecosystem services

(Kremer et al. 2013, Gardiner et al. 2013, Haase et al. 2014, Kim 2016). 
Because of the diversity of ecosystem services they provide, urban forests represent a valuable resource to residents of inner cities and suburbs (Tyrväinen et al. 2005, Mullaney et al. 2015). Urban trees play an important role in sequestering carbon, mitigating the heat island effect (Rosenfeld et al. 1998, Akbari et al. 2001), improving air quality (Nowak et al. 2006, 2014), and reducing stormwater runoff (Xiao and McPherson 2002). They can also enhance property values, improve human health and well-being, and foster a greater sense of social connectivity (Ulrich 1984, Tyrväinen and Miettinen 2000, Tyrväinen et al. 2005, Payton et al. 2008, Gopal and Nagendra 2014). The benefits of urban forests, however, can be inequitably distributed when tree canopy cover and access to green spaces vary along socio-economic gradients (Pedlowski et al. 2002, Heynen 2003, Heynen et al. 2006, Landry and Chakraborty 2009, Wolch 2014).

The composition, structure, function, and value of urban forests are influenced by a number of factors, including historic plant communities, local stakeholders, differing management regimes, and legacies of land use and development (Alvey 2006, Burkholder 2012). This is especially true for the forest community on inner-city and suburban residential lots, where differences in neighborhood age and community affluence can influence tree abundance and diversity (Kinzig et al. 2005, Conway and Bourne 2013). Furthermore, the transition from residential to vacant lots may alter the tree community in a variety of ways, but little is known about how the urban forest on inner-city vacant lots differs from that on inner-city or suburban residential lots.

Exotic tree species are common in many cities (Alvey 2006, dos Santos et al. 2010, Aronson et al. 2015), which may influence the ecological and economic value of urban forests. The negative impacts of exotic species have been widely documented (Simberloff 2005, Rejmánek and Richardson 2013). However, there has been less focus on ecological benefits that 
exotic trees might provide (Goodenough 2010, Dickie et al. 2014). Hence, there exists a need to document the benefits as well as costs of exotic trees to urban forests, and to assess how they compare with native taxa.

The shrinking city of Cleveland, Ohio experienced the third greatest population decline in the United States from 1960-2000 (Schilling and Logan 2008) and lost over half of its population since its peak in the 1950s (Blanco et al. 2009). The demolition of houses and other infrastructure has created more than 27,000 vacant lots (James Greene, personal communication, July 7, 2016) spanning over 1,300 hectares (Cleveland Land Lab 2008). Following demolition, most lots are planted with turfgrass and mown periodically with little additional management. The objectives of this study were to document the abundance, richness, diversity, ecosystem services, and economic value of native and exotic tree species on vacant lots within inner-city Cleveland, $\mathrm{OH}$, and compare them with inner-city residential lots located in the same neighborhoods, as well as suburban residential lots located immediately outside the city proper that may be more intensely landscaped and managed. We tested the following hypotheses: 1) tree abundance, richness, and diversity would be greatest on suburban residential lots; 2) exotic trees would be more abundant on inner-city vacant and residential lots; and 3) the quantity and economic value of ecosystem services provided by trees would be greatest on suburban residential lots.

\section{Methods}

\subsection{Study area and lot selection}

The study was carried out within Cleveland, $\mathrm{OH}\left(41.49^{\circ} \mathrm{N}, 81.69^{\circ} \mathrm{W}\right)$ and surrounding suburbs in Cuyahoga County from April - August 2015 (Fig. 1). As of 2010, Cleveland had the 
second largest population in Ohio and Cuyahoga County was the state's most populous county (U.S. Census Bureau 2012). Forest communities were inventoried on three property types: 1) inner-city vacant lots, 2) inner-city residential lots, and 3) suburban residential lots (Fig. 1). Vacant and inner-city residential lots were located within eight inner-city Cleveland neighborhoods: Broadway-Slavic Village, Buckeye-Woodhill, Central, Detroit Shoreway, Fairfax, Glenville, Hough, and Tremont (Fig. 1). Suburban residential lots were located within eight inner-ring suburban communities immediately adjacent to the city: Brook Park, Brooklyn, Cleveland Heights, Euclid, Fairview Park, Garfield Heights, Lakewood, and Shaker Heights (Fig. 1).

Lots were selected from a database obtained from the Cleveland City Planning Commission with information on all land parcels in Cuyahoga County as of 2014. For each inner-city neighborhood, we initially randomly selected eight single-family residential lots (LUC $=5100)$ and eight vacant lots $(\mathrm{LUC}=5000)$ using the database attributes parcel number, address, land use code (LUC), and size. Residential lots had an occupied house while vacant lots were devoid of any structure and often had been planted with turfgrass following demolition of an abandoned house. All lots ranged in size from 0.04 to 0.06 ha (mean for all three property types $=0.05 \mathrm{ha}$ ). This size range was used because it is highly representative of lots in both the inner city and surrounding suburbs.

The selection process yielded a stratified random sample of inner-city vacant and residential lots, which served as our sample units. We performed the same sampling procedure for each suburb in order to select residential lots to sample, but did not select vacant lots. When we were denied permission to sample lots, unable to access them, or they were otherwise found to be unsuitable, additional lots were selected at random by re-sampling the database. 


\subsection{Urban forest characterization}

Between May - August 2015, 53 inner-city vacant lots, 54 inner-city residential lots, and 56 suburban residential lots were surveyed (163 total lots). Property type and neighborhood/community were rotated daily to avoid bias associated with seasonal or spatial variation. Surveys followed the methodology of Nowak et al. (2008) and the urban forest assessment protocol (i-Tree Eco User's Manual v5.0. n.d.) for i-Tree Eco, an urban forest analysis tool within the peer-reviewed, public domain i-Tree Software Suite v5.0. (i-Tree Eco v5.0. n.d.) developed by the USDA Forest Service and cooperators. For each lot, we estimated the amount of tree and ground cover within the following categories: building, cement, tar, rock, bare soil, duff/mulch, herbaceous cover, grass, unmaintained grass, and water. All living and dead trees with a stem diameter at breast height ( $\mathrm{DBH}$, measured $1.37 \mathrm{~m}$ above ground) $\geq 2.54$ $\mathrm{cm}$ were surveyed, with establishment status (i.e., planted, naturally regenerated, or unknown), whether it was a street tree (located in right-of-way between sidewalk and street), total tree height, height to live top, height to crown base, crown width in north-south and east-west directions, DBH, percent crown missing, percent crown dieback, crown light exposure, percent impervious surface under the tree, and percent shrub cover under the tree were recorded. Additionally, for all trees $\geq 6 \mathrm{~m}$ in height, distance and direction to the three nearest spaceconditioned residential buildings (buildings shaded by trees) located within $18 \mathrm{~m}$ of the tree were recorded.

All living trees were identified to genus, and in almost all cases to species. Dead trees that could not be identified to species or genus were classified as a hardwood (Magnoliopsida) or softwood (Pinopsida). Trees were also classified as native or exotic to North America following the USDA Natural Resources Conservation Service Plants Database (USDA NRCS 2016) and 
Dirr (2009). Dead trees were included in all analyses except when knowledge of continental origin was required, in which case the 18 trees of unknown origin were omitted.

\subsection{Tree abundance, richness, and diversity}

We determined the effect of property type (inner-city vacant lot, inner-city residential lot, or suburban residential lot) on tree abundance (total number of trees per lot), street tree abundance (number of street trees per lot), taxonomic richness (number of tree species per lot, or species plus genera when unable to identify a particular species), and tree diversity (Shannon diversity index value (H') per lot) via ANOVA using generalized linear models (GLM) in R (R Core Team 2014). We also examined effects of tree origin (native or exotic) and property type on tree abundance with two-way analysis of variance. Tree abundance, taxonomic richness, and the abundance of native and exotic taxa were modeled with a negative binomial distribution; street tree abundance was modeled with a Poisson distribution; and tree diversity was modeled with a Gaussian distribution. The "Anova" function in the "car" package (Fox and Weisberg 2011) was used to generate analysis of deviance tables from which likelihood-ratio test statistics were obtained. Means were separated with Tukey contrasts using the "ghlt" function in the "multcomp" package (Hothorn 2008). All analyses described in section 2.3. were conducted in R (R Core Team 2014). An alpha level of 0.05 was specified for all statistical tests.

\subsection{Urban forest community comparisons}

To evaluate similarity among and between property types based on the composition of taxa on individual lots we ordinated lots using nonmetric multi-dimensional scaling (NMDS) in R. The "rankindex" function in the "vegan" package (Oksanen et al. 2016) was used to identify the Euclidean dissimilarity index as the optimal index for ordination. The community data were transformed with a Wisconsin double standardization and square root transformation, which 
lowered the stress of the ordination and improved fit (Minchin 1987). The "metaMDS" function in the "vegan" package was used to perform the ordination, and three dimensions were specified to minimize stress. Permutational multivariate ANOVA was used to test for an overall difference in community composition between the three property types using the "adonis" function in the "vegan" package in R while multi-response permutation procedures (MRPP) was used to test for pairwise differences between property types using PC-ORD Version 5 (McCune and Grace 2002).

\section{5. i-Tree Eco: Urban forest composition and structure}

We used our survey data with i-Tree Eco to model forest composition (proportion of each species) and structure (physical characteristics of trees and forest) of each property type. We used i-Tree Eco to estimate percentage of the population and percent total leaf area for each taxon, which were summed to produce an importance value ranging from 0-200, with higher values indicative of greater dominance on a property type, as well as tree size class distributions, tree density, total leaf area, total leaf biomass, and total canopy cover for each property type.

\section{6. i-Tree Eco: Ecosystem services}

Ecosystem services and their monetary values provided by trees on each property type were also modeled on a per hectare basis from survey data by i-Tree Eco, including carbon sequestration, carbon storage, and oxygen production. Energy effects and savings, avoided stormwater runoff and savings, and atmospheric pollutant removal values were estimated for the cumulative area of each property type, and were standardized on a per hectare basis in order to compare the three property types. Monetary values of estimated ecosystem service outputs were also generated for each taxonomic group, and the percentage contribution of native and exotic taxa to the total monetary value was determined for each property type. 


\section{Results}

A total of 1,196 trees representing 50 genera and at least 76 species were inventoried. Of the 1,196 trees, 1,088 were identified to species (representing 76 species), 90 individuals were identified to genera only (representing 8 genera), and 18 dead trees were identified as hardwood or softwood. Most individuals (61\%) belonged to three genera: Acer (23\%), Morus (21\%), and Ulmus (17\%); while 34 genera each accounted for less than $1 \%$ of the total number of trees (Table 1). When all lots within a property type were combined, inner-city residential lots had more total genera (34) than suburban residential (33) or inner-city vacant lots (25)(Table 1). On inner-city vacant lots, Acer, Morus, and Ulmus were the most common genera, accounting for $74 \%$ of taxa. On inner-city residential lots, Acer, Ailanthus, and Morus were the most common genera, accounting for $45 \%$ of taxa, while Acer, Morus, and Thuja accounted for $49 \%$ of all taxa on suburban residential lots.

\subsection{Tree abundance, richness, and diversity}

Tree abundance (ANOVA, $\left.\chi^{2}=82.0(2, N=163), P<0.001\right)$ and taxonomic richness (ANOVA, $\left.\chi^{2}=18.5(2, N=163), P<0.001\right)$ varied among the three property types. On average, inner-city vacant lots supported more than three times as many trees and greater taxonomic richness than the two residential property types, which did not differ (Fig. 2A). Property types also varied in abundance of native versus exotic trees (ANOVA, $\chi^{2}=4.6(1, N=326), P=$ 0.03)(Fig. 2B). Exotic trees were more abundant than native trees on inner-city vacant lots, however there was no difference in average abundance of exotic and native trees on inner-city or suburban residential lots (Fig. 2B). Average abundance of street trees also varied among property types (ANOVA, $\left.\chi^{2}=8.7(2, N=163), P=0.013\right)$. There were more street trees on 
suburban residential lots than on inner-city vacant lots, but there was no difference in street tree abundance between suburban and inner-city residential lots, or between inner-city residential and vacant lots (Fig. 2C). Lastly, tree diversity $\left(\mathrm{H}^{\prime}\right)$ varied among the three property types (ANOVA, $\left.\chi^{2}=9.2(2, N=163), P=0.01\right)$, with inner-city vacant lots having a higher average Shannon diversity index value than inner-city residential lots (Fig. 2D). However, the difference between inner-city vacant lots and inner-city residential lots was not significant, nor was the difference between inner-city residential and suburban residential lots (Fig. 2D).

\subsection{Urban forest community comparisons}

There was a high degree of overlap in forest community composition between the three property types as indicated by NMDS ordination (Fig. 3). The forest community on inner-city vacant lots was largely a subset of that on the two residential property types, and was the most similar among lots within a property type (Fig. 3). There was a reasonable fit of the model to the data as evidenced by the Shepard's diagram and a stress value of 0.180 for the final threedimensional solution. The ADONIS analysis indicated a significant difference in the grouping of

sites (ADONIS, $F=6.7, P<0.001$ ); however, less than $10 \%$ of the variation in distance matrices was explained by this grouping pattern $\left(R^{2}=0.08\right)$.

The pairwise comparisons of the MRPP analysis indicated that the greatest difference in forest communities was between inner-city vacant and suburban residential lots $(T=-29.6, P<$ $0.001, A=0.085)$, the two residential property types were most $\operatorname{similar}(T=-15.0, P<0.001, A=$ 0.029), and inner-city vacant and residential lots were intermediate $(T=-21.8, P<0.001, A=$ 0.066). An effect size (A) of less than 0.1 is common for ecological data (Grace and McCune 2002).

\section{3. i-Tree Eco: Urban forest composition and structure}


According to i-Tree Eco, the three most common species on inner-city vacant lots were Morus alba L., Acer platanoides L., and Ulmus americana L., which collectively comprised 49\% of all trees (Table 2). Morus alba, Acer platanoides, and Ailanthus altissima Mill. were the three most common species on inner-city residential lots, where they comprised $43 \%$ of all trees, while Thuja spp., Acer saccharinum L., and Morus alba were the three most common species on suburban residential lots, representing $32 \%$ of all trees (Table 2). Morus alba had the highest importance value on both inner-city property types, while Acer saccharinum and Acer platanoides ranked among the three most important species for all three property types (Table 2).

On inner-city vacant and residential lots, $46 \%$ of trees were in the smallest DBH size class $(0-7.6 \mathrm{~cm})$, while only $23 \%$ of trees on suburban residential lots were in that range (Fig. 4). Conversely, on suburban residential lots, $32 \%$ and $19 \%$ of trees were in the next two largest size classes (7.7-15.2 and 15.3-22.9 cm, respectively), compared with $23 \%$ and $11 \%$ on inner-city vacant lots, and $17 \%$ and $8 \%$ on inner-city residential lots, respectively (Fig. 4). No property type had more than $10 \%$ of its tree population in the $23.0-30.5 \mathrm{~cm}$ or larger size class (Fig. 4). Using tree abundance, size class, percent crown missing and dieback, and canopy cover data, iTree Eco estimated that inner-city vacant lots supported three times as many trees, two times as much leaf area and leaf biomass, and more tree canopy cover than the two residential property types (Table 3).

\section{4. i-Tree Eco: Ecosystem services}

Carbon sequestration, carbon storage, oxygen production, carbon emissions avoided through energy savings, and stormwater runoff avoided were greater on inner-city vacant lots than on the two residential property types (Table 4). The greater energy effects and stormwater benefits translated into greater monetary value of these ecosystem services provided by the forest 
community on inner-city vacant lots (Table 5). The amount of carbon monoxide, nitrogen dioxide, ozone, sulfur dioxide, and particulate matter annually removed by a hectare of urban forest was also greatest on inner-city vacant lots, as modeled by i-Tree Eco (Table 4). This translated into greater monetary value of these ecosystem services provided by trees on innercity vacant lots relative to the two residential property types (Table 5).

The percentage monetary value of ecosystem services provided by native and exotic taxa on each property type also varied. On inner-city vacant lots, $52 \%$ of the total monetary value was attributable to exotic taxa. On residential lots, however, the value of ecosystem services provided by native taxa was much higher than for exotic taxa, which accounted for only $30 \%$ and $26 \%$ of the total value on inner-city and suburban residential lots, respectively.

\section{Discussion}

Contrary to our a priori hypotheses, tree abundance and taxonomic richness were greater on inner-city vacant lots in Cleveland, $\mathrm{OH}$ than on inner-city or suburban residential lots, as were the quantity and economic value of ecosystem services. Tree diversity was also greater on innercity vacant lots than on inner-city residential lots. These patterns can likely be attributed in part to the greater abundance of naturally regenerated exotic trees and lower abundance of planted street and landscape trees on inner-city vacant lots than on the two residential property types.

\subsection{Tree abundance, richness, and diversity}

On average, inner-city vacant lots were taxonomically richer, supported three times as many trees, and twice as much total leaf area and leaf biomass as inner-city and suburban residential lots, and had a higher Shannon diversity index than inner city residential lots. However, combined across all replicate lots, the total number of tree taxa on both inner-city and 
suburban residential lots was greater than the total number of taxa on inner-city vacant lots. The Shannon diversity index is a function of species evenness (distribution of abundance among species) as well as richness (Smith and Wilson 1996). Hence, the high diversity on inner-city vacant lots, even with fewer total taxa across all lots combined, is due to high average evenness as well as high average richness. This pattern resulted largely from the relative uniform species composition and abundance of naturally regenerated saplings on inner city vacant lots compared with residential property types, which contained low abundances of diverse horticultural species that were probably planted by residents. Ordination analysis confirmed this pattern, revealing a high degree of overlap in forest community composition among the three property types, with that on inner-city vacant lots largely representing a subset of those on the two residential property types. Additionally, the ordination showed that the forest community composition among inner-city vacant lots was more homogenous than that of inner-city or suburban residential lots.

Inner-city vacant lots were dominated by only three genera (Morus, Acer, and Ulmus), which comprised $74 \%$ of all individuals. Furthermore, $49 \%$ of all taxa belonged to only three species: Morus alba, Acer platanoides, and Ulmus americana. Morus alba and Acer saccharinum had the highest importance values on inner-city vacant lots, while Acer platanoides had a higher importance value than Ulmus americana despite accounting for a smaller percentage of the overall population, perhaps because it often succumbs to Dutch elm disease before reaching maturity.

Morus alba, Acer platanoides, and Ailanthus altissima were the three most common species on inner-city residential properties, where they comprised $43 \%$ of all trees. As was the case with inner-city vacant lots, Morus alba, Acer saccharinum, and Acer platanoides had the 
highest importance values. Because of the small size distribution of Ailanthus altissima, an early successional colonizer, its importance was not proportional to its high abundance on inner-city residential lots, but this may change over time as saplings continue to grow.

On suburban residential lots, Thuja species and cultivars were the most common taxa due to their widespread use as an ornamental landscape plant, followed by Acer saccharinum, and Morus alba. Acer saccharinum and Acer platanoides were the two most important species on suburban residential lots. Despite consisting of just over 2\% of the population, Quercus palustris Münchh. was the third most important species on suburban residential properties because of its large average trunk diameter and total leaf area.

\subsection{Urban forest structure}

Inner-city vacant lots were characterized by extensive urban spontaneous vegetation (USV), which has been defined as vegetation that colonizes and undergoes succession on unmanaged land in and around cities (Robinson and Lundholm 2012). Across all inner-city vacant lots, $80 \%$ of trees were in the smallest three size classes $(0-22.9 \mathrm{~cm})$, and $94 \%$ of trees were naturally regenerated rather than planted, compared to just $53 \%$ on inner-city residential lots and $31 \%$ on suburban residential lots. Robinson and Lundholm (2012) also observed that sites dominated by USV had greater plant species richness and diversity than managed lawns or semi-natural forests. Nowak et al. (2001) reported that vacant land in Syracuse, NY supported over three times as many trees per acre as residential land cover, with $81 \%$ of trees having a DBH of $\leq 23 \mathrm{~cm}$. Similarly, Zipperer (2002) documented a greater density of smaller trees (DBH $\leq 29.9 \mathrm{~cm})$ and lower density of larger trees $(\mathrm{DBH} \geq 40.0 \mathrm{~cm})$ on regenerated forest patches in urban forests, as well as a greater leaf area for trees on vacant versus residential land. These findings coupled with ours suggest that USV is ecologically significant in urban forests in 
general, and on vacant land in particular, with the potential to support biodiversity and provide substantial ecosystem services.

While USV can be viewed as a low-input component of urban forests, street trees require significant monetary inputs to support their establishment and management (Soares et al. 2016). We recorded more than twice as many street trees on suburban residential lots as we did on inner-city vacant lots. There were also more street trees on suburban residential lots than on inner-city residential lots, although the difference was not statistically significant. These patterns suggest inequity in the distribution of street trees across communities in Cuyahoga County. However, Cleveland recently initiated an urban reforestation program (Atassi 2014) in an effort to increase its community-wide tree canopy, which in a recent assessment ranked 57 among Cuyahoga County’s 59 municipalities (Cuyahoga County Urban Tree Canopy Assessment 2013).

\section{3. i-Tree Eco: Ecosystem services}

Trees on inner-city vacant lots provided a greater quantity of regulating ecosystem services including carbon sequestration and storage, oxygen production, energy savings, stormwater runoff reduction, and the removal of atmospheric pollutants such as carbon monoxide and particulate matter on a per hectare basis than did trees on suburban and inner-city residential lots. The combined value per hectare for those services for which a monetary value was generated (energy savings, stormwater runoff reduction, and atmospheric pollutant removal) was more than two times greater on vacant lots than inner-city residential lots and more than three times greater on vacant lots than on suburban residential lots. Although i-Tree Eco does not provide the user with monetary values for carbon sequestration and storage and oxygen production, their output and presumably their economic value was also greater on vacant lots. Zipperer (2002) also found that carbon storage and sequestration by urban trees was greater on 
vacant land than on residential properties. The net value of ecosystem services of trees on vacant land relative to more highly managed trees is probably even greater than estimated, as there are fewer to no costs associated with their planting or maintenance as many are naturally regenerated (Zipperer 2002). Therefore, with limited resources to invest by local municipalities (Zipperer 2002), the naturally regenerated trees on vacant lots represent a substantial and undoubtedly undervalued resource to inner-city neighborhoods.

\subsection{Role and potential value of exotic tree species}

Exotic species represented the majority of trees on inner-city vacant lots, and half the population on inner-city and suburban residential lots. Based on the i-Tree Eco models, exotic taxa are also providing a significant proportion of the ecosystem services provided by the urban forest. On inner-city vacant lots in particular, exotic taxa generated over half of the total value provided by the urban forest on this property type, while native species provided proportionally much greater economic value on residential lots. Clearly, exotic trees are serving an important role in providing ecosystem services within the inner city.

While many studies document ecological and economic impacts of alien invasive species (Pimentel et al. 2005, Simberloff 2005, Rejmánek and Richardson 2013), comparatively few have assessed their benefits (Foster and Sandberg 2004, Schlaepfer et al. 2011). For example, Dickie et al. (2014) highlighted the ecosystem services provided by certain invasive tree genera, while acknowledging their potential for harm. Many exotic tree species are well adapted to harsh urban environments - a consideration that is even more important in the face of climate change (Roloff et al. 2009, Chalker-Scott 2015). The many stressors such as heat, drought, pollution, and soil compaction that are often characteristic of urban ecosystems make the incorporation of stress-tolerant taxa in the urban forest a priority for long-term resilience (Sjöman et al. 2016). As 
we observed, exotic species can also contribute to increased diversity, which can promote ecosystem function and increase ecosystem productivity (Jim and Liu 2001, Hooper et al. 2005), as well as mitigate the risk of wide-scale deforestation following the introduction of alien insects and pathogens (Raupp et al. 2010).

A legitimate concern, however, surrounding the ecological impact and conservation value of exotic trees in urban environments is their potential inability to support a diversity of native fauna comparable to their native counterparts, resulting in decreased food web complexity (Tallamy 2004). For example, Burghardt et al. (2008) found that suburban residential properties landscaped entirely with native plants supported more caterpillars and caterpillar species, as well as greater bird diversity and abundance, than properties landscaped with a mixture of native and exotic plants. In manipulative common garden experiments, Burghardt and Tallamy (2013) and Ballard et al. (2013) also found that exotic plant species supported lower biodiversity across trophic levels. Conversely, in a series of assays Morrison and Hay (2011) observed that generalist herbivores preferred exotic plants that were evolutionarily naïve, while Burghardt and Tallamy (2015) showed that non-native plant species with native congeners contributed as much to insect herbivore diversity as native plant species. The effects of exotic tree species on the diversity and abundance of higher trophic levels in urban forests largely remains to be investigated.

Davis et al. (2011) argued that exotic species provide valuable economic and ecological benefits in some ecosystems, which is clearly the case for the urban forest on inner-city vacant land of Cleveland. When considering the ecological value of exotic, naturally regenerated urban trees, perhaps the most important consideration should be whether or not resources exist to actively remove and replace them with native species. This may not generally be the case in 
shrinking cities. As our study showed, exotic trees are providing substantial, economically valuable ecosystem services on inner-city vacant lots in Cleveland, free of costly human intervention and inputs such as fertilizer and pesticides. Therefore, a balanced and thorough assessment of the benefits as well as the costs associated with exotic trees is critical for the strategic management of inner-city urban forests.

\section{Acknowledgements}

The authors would like to thank Alexander Clark, Ginelle Doerr, and Christy Mendiola for their help with lot surveys and data collection, Scott Maco (The Davey Tree Expert Company) for his assistance with i-Tree Eco, Thomas Jordan (Cleveland City Planning Commission) for providing and assisting with the Cuyahoga County data set and lot selection, Christina Voice (Chadwick Arboretum) and James A. Chatfield (The Ohio State University) for their assistance with tree identification, and members of the Ag-Urban Landscape Ecology Lab for their support of this project. Financial support was provided from the National Science Foundation NSF CAREER program (CAREER 1253197), the National Science Foundation Graduate Research Fellowship Program (DGE-1343012), and state and federal funds appropriated to Ohio Agricultural Research and Development Center and The Ohio State University.

\section{References}

Accordino, J., and G. T. Johnson. 2000. Addressing the vacant and abandoned property problem. Journal of Urban Affairs 22:301-315.

Akbari, H., M. Pomerantz, and H. Taha. 2001. Cool surfaces and shade trees to reduce energy use and improve air quality in urban areas. Solar Energy 70:295-310.

Alexander, F. S. 2005. Land bank authorities: A guide for the creation and operation of local land banks. Local Initiative Support Corporation.

Alvey, A. 2006. Promoting and preserving biodiversity in the urban forest. Urban Forestry and Urban Greening 5:195-201. 
Aronson, M. F. J., S. N. Handel, I. P. La Puma, and S. E. Clemants. 2015. Urbanization promotes non-native woody species and diverse plant assemblages in the New York metropolitan region. Urban Ecosystems 18:31-45.

Atassi, L. 2014. Cleveland to plant 1,000 trees in five neighborhoods, start of long-term reforestation initiative. Retrieved 24 August 2016 from: http://www.cleveland.com/cityhall/index.ssf/2014/03/cleveland_to_plant_1000_trees.html

Ballard, M., J. Hough-Goldstein, and D. Tallamy. 2013. Arthropod communities on native and nonnative early successional plants. Environmental Entomology 42:851-859.

Blanco, H., M. Alberti, R. Olshansky, S. Chang, S. M. Wheeler, J. Randolph, J. B. London, J. B. Hollander, K. M. Pallagst, T. Schwarz, F. J. Popper, S. Parnell, E. Pieterse, and V. Watson. 2009. Shaken, shrinking, hot, impoverished and informal: Emerging research agendas in planning. Progress in Planning 72:195-250.

Bonham, J. B., G. Spilka, and D. Rastorfer. 2002. Old cities/green cities: Planning advisory service report number 506/507. American Planning Association: Chicago, IL, USA.

Burghardt, K. T., and D. W. Tallamy. 2013. Plant origin asymmetrically impacts feeding guilds and life stages driving community structure of herbivorous arthropods. Diversity and Distributions 19:1553-1565.

Burghardt, K. T., and D. W. Tallamy. 2015. Not all non-natives are equally unequal: Reductions in herbivore $\beta$-diversity depend on phylogenetic similarity to native plant community. Ecology Letters 18:1087-1098.

Burghardt, K. T., D. W. Tallamy, and W. G. Shriver. 2009. Impact of native plants on bird and butterfly biodiversity in suburban landscapes. Conservation Biology 23:219-224.

Burkholder, S. 2012. The new ecology of vacancy: Rethinking land use in shrinking cities. Sustainability 4:1154-1172.

Chalker-Scott, L. 2015. Nonnative, noninvasive woody species can enhance urban landscape biodiversity. Arboriculture and Urban Forestry 41:173-186.

Cleveland Land Lab. 2008. Re-imagining a more sustainable Cleveland: Citywide strategies for reuse of vacant land. Retrieved 24 August 2016 from: http://www.reconnectingamerica.org/assets/Uploads/20090303ReImaginingMoreSustainabl eCleveland.pdf

Conway, T. M., and K. S. Bourne. 2013. A comparison of neighborhood characteristics related to canopy cover, stem density and species richness in an urban forest. Landscape and Urban Planning 113:10-18.

Cuyahoga County Urban Tree Canopy Assessment. 2013. Retrieved 24 August 2016 from: http:/www.countyplanning.us/projects/urban-tree-canopy-assessment

Davis, M. A., M. C. Chew, R. J. Hobbs, A. E. Lugo, J. J. Ewel, G. J. Vermeij, J. H. Brown, M. L. Rosenzweig, M. R. Gardener, S. P. Carroll, K. Thompson, S. T. A. Pickett, J. C. Stromberg, P. Del Tredici, K. N. Suding, J. G. Ehrenfeld, J. P. Grime, J. Mascaro, and J. C. Briggs. 2011. Don't judge species on their origins. Nature 474:153-154.

Dickie, I. A., B. M. Bennett, L. E. Burrows, M. A. Nuñez, D. A. Peltzer, A. Porté, D. M. Richardson, M. Rejmánek, P. W. Rundel, and B. W. van Wilgen. 2014. Conflicting values: Ecosystem services and invasive tree management. Biological Invasions 16:705-719.

Dirr, M. 2009. Manual of woody landscape plants: Their identification, ornamental characteristics, culture, propagation and uses. Champaign, IL. Stipes Pub.

Floater, G., P. Rode, A. Robert, C. Kennedy, D. Hoornweg, R. Slavcheva, and N. Godfrey. 2014. Cities and the new climate economy: The transformative role of global urban growth. New 
Climate Economy Cities Paper 01. LSE Cities. London School of Economic and Political Science.

Foster, J., and L. A. Sandberg. 2004. Friends or foe? Invasive species and public green space in Toronto. Geographical Review 94:178-198.

Fox, J., and S. Weisberg. 2011. An R Companion to Applied Regression, Second Edition. Thousand Oaks CA: Sage. Available from: http://socserv.socsci.mcmaster.ca/jfox/Books/Companion

Gardiner, M. M., C. E. Burkman, and S. P. Prajzner. 2013. The value of urban vacant land to support arthropod biodiversity and ecosystem services. Environmental Entomology 42:1123-1136.

Goodenough, A. E. 2010. Are the ecological impacts of alien species misrepresented? A review of the "native good, alien bad" philosophy. Community Ecology 11:13-21.

Gopal, D., and H. Nagendra. 2014. Vegetation in Bangalore's slums: Boosting livelihoods, wellbeing and social capital. Sustainability (Switzerland) 6:2459-2473.

Green, O.O., A.S. Garmestani, S. Albro, N. Ban, A. Berland, C. Burkman, M.M. Gardiner, L.H. Gunderson, M.E. Hopton, M. Schoon and W.D. Shuster. 2016. Adaptive governance to promote ecosystem services in urban green spaces. Urban Ecosystems 19:77-93.

Grimm, N. B., S. H. Faeth, N. E. Golubiewski, C. L. Redman, J. Wu, X. Bai, and J. M. Briggs. 2008. Global change and the ecology of cities. Science 319:756-760.

Haase, D., A. Haase, and D. Rink. 2014. Conceptualizing the nexus between urban shrinkage and ecosystem services. Landscape and Urban Planning 132:159-169.

Heynen, N. C. 2003. The scalar production of injustice within the urban forest. Antipode. 35:980-998.

Heynen, N. C., H. A. Perkins, and P. Roy. 2006. The political ecology of uneven urban green space: The impact of political economy on race and ethnicity in producing environmental inequality in Milwaukee. Urban Affairs Review 42:3-25.

Hooper, D. U., C. F. S. Chapin III, J. J. Ewel, A. Hector, P. Inchausti, S. Lavorel, J. H. Lawton, D. M. Lodge, M. Loreau, and S. Naeem. 2005. Effects of biodiversity on ecosystem functioning: a consensus of current knowledge. Ecological Monographs 75:3-35.

Hothorn, T., F. Bretz, and P. Westfall. 2008. Simultaneous inference in general parametric models. Biometrical Journal 50:346-363.

i-Tree Eco User's Manual v5.0. n.d. Retrieved 24 August 2016 from: https://www.itreetools.org/resources/manuals/Eco_Manual_v5.pdf

i-Tree Eco v5.0. n.d. Retrieved 24 August 2016 from: https:/www.itreetools.org/eco/index.php

Jim, C. Y., and H. T. Liu. 2001. Species diversity of three major urban forest types in Guangzhou City, China. Forest Ecology and Management 146:99-114.

Kim, G. 2016. The public value of urban vacant land: Social responses and ecological value. Sustainability 8:486.

Kinzig, A. P., P. Warren, C. Martin, D. Hope, and M. Katti. 2005. The effects of human socioeconomic status and cultural characteristics on urban patterns of biodiversity. Ecology and Society 10:23.

Kremer, P., Z. A. Hamstead, and T. McPhearson. 2013. A social-ecological assessment of vacant lots in New York City. Landscape and Urban Planning 120:218-233.

Landry, S. M., and J. Chakraborty. 2009. Street trees and equity: evaluating the spatial of an urban amenity. Environment and Planning 41:2651-2670.

Martinez-Fernandez, C., I. Audirac, S. Fol, and E. Cunningham-Sabot. 2012. Shrinking cities: 
Urban challenges of globalization. International Journal of Urban and Regional Research $36: 213-225$.

McCune, B. and J. B. Grace. 2002. Analysis of ecological communities. MJM Software, Gleneden Beach, Oregon, USA.

Minchin, P. R. 1987. An evaluation of relative robustness of techniques for ecological ordinations. Vegetatio 69:89-107.

Morrison, W. E., and M. E. Hay. 2011. Herbivore preference for native vs. exotic plants: Generalist herbivores from multiple continents prefer exotic plants that are evolutionarily naïve. PLoS ONE 6: e17227.

Mullaney, J., T. Lucke, and S. J. Trueman. 2015. A review of benefits and challenges in growing street trees in paved urban environments. Landscape and Urban Planning 134:157-166.

Nowak, D. J., and P. O'Connor. 2001. Syracuse urban forest master plan: Guiding the city's forest resource in the $21^{\text {st }}$ century. USDA Forest Service General Technical Report.

Nowak, D. J., D. E. Crane, and J. C. Stevens. 2006. Air pollution removal by urban trees and shrubs in the United States. Urban Forestry and Urban Greening 4:115-123.

Nowak, D. J., D. E. Crane, J. C. Stevens, R. E. Hoehn, J. T. Walton, and J. Bond. 2008. A ground-based method of assessing urban forest structure and ecosystem services. Arboriculture \& Urban Forestry 34:347-358.

Nowak, D. J., S. Hirabayashi, A. Bodine, and E. Greenfield. 2014. Tree and forest effects on air quality and human health in the United States. Environmental Pollution 193:119-129.

Oksanen, J., F. G. Blanchet, R. Kindt, P. Legendre, P. R. Minchin, R. B. O'Hara, G. L. Simpson, P. Solymos, M. Henry, H. Stevens, and H. Wagner. 2016. Vegan: Community Ecology Package. R package version 2.3-4. Available from: http://CRAN.R-project.org/package= vegan

Pagano, M. A., and A. Bowman. 2004. Vacant land as opportunity and challenge. In R. Greenstein and Y. Sungu-Ermilyaz (Eds.), Recycling the City: The Use and Reuse of Urban Land (pp. 15-32). Cambridge, MA: Lincoln Institute of Land Policy.

Payton, S., G. Lindsey, J. Wilson, J. R. Ottensmann, and J. Man. 2008. Valuing the benefits of the urban forest: A spatial hedonic approach. Journal of Environmental Planning and Management 51:717-736.

Pedlowski, M. A., V. A. C. Da Silva, J. J. C. Adell, and N. C. Heynen. 2002. Urban forest and environmental inequality in Campos dos Goytacazes, Rio de Janeiro, Brazil. Urban Ecosystems 6:9-20.

Pimentel, D., R. Zuniga, and D. Morrison. 2005. Update on the environmental and economic costs associated with alien-invasive species in the United States. Ecological Economics 52:273-288.

R Core Team. 2014. R: A language and environment for statistical computing. R Foundation for Statistical Computing, Vienna, Austria. Available at: http://www.R-project.org

Raupp, M. J., P. M. Shrewsbury, and D. A. Herms. 2010. Ecology of herbivorous arthropods in urban landscapes. Annual Review of Entomology 55:19-38.

Rejmánek, M., and D. Richardson. 2013. Trees and shrubs as invasive alien species-2013 update of the global database. Diversity and Distributions 19:1093-1094.

Robinson, S. L., and J. T. Lundholm. 2012. Ecosystem services provided by urban spontaneous vegetation. Urban Ecosystems 15:545-557.

Roloff, A., S. Korn, and S. Gillner. 2009. The Climate-Species-Matrix to select tree species for urban habitats considering climate change. Urban Forestry and Urban Greening 8:295-308. 
Rosenfeld, A. H., H. Akbari, J. J. Romm, and M. Pomerantz. 1998. Cool communities: Strategies for heat island mitigation and smog reduction. Energy and Buildings 28:51-62.

Rybczynski, W., and P. Linneman. 1999. How to save our shrinking cities. Public Interest 30-44. dos Santos, A. R., C. F. D. da Rocha, and H. G. Bergallo. 2010. Native and exotic species in the urban landscape of the city of Rio de Janeiro, Brazil: Density, richness, and arboreal deficit. Urban Ecosystems 13:209-222.

Schilling, J., and J. Logan. 2008. Greening the Rust Belt. Journal of the American Planning Association 74:451-466.

Schlaepfer, M. A., D. F. Sax, and J. D. Olden. 2011. The potential conservation value of nonnative species. Conservation Biology 25:428-437.

Simberloff, D. 2005. Non-native species DO threaten the natural environment! Journal of Agricultural and Environmental Ethics 18:595-607.

Sjöman, H., J. Morgenroth, J. Deak, S. A. Saebø, and I. Kowarik. 2016. Diversification of the urban forest - can we afford to exclude exotic tree species? Urban Forestry \& Urban Greening 18:237-241.

Smith, B. and J.B. Wilson. 1996. A consumer's guide to evenness indices. Oikos 76:70-82.

Soares, A. L., F. C. Rego, E. G. McPherson, J. R. Simpson, P. J. Peper, and Q. Xiao. 2016. Benefits and costs of street trees in Lisbon, Portugal. Urban Forestry and Urban Greening 10:69-78.

Tallamy, D. W. 2004. Do alien plants reduce insect biomass? Conservation Biology 18:16891692.

Tyrväinen, L., and A. Miettinen. 2000. Property prices and urban forest amenities. Journal of Environmental Economics and Management 39:205-223.

Tyrväinen, L., S. Pauleit, K. Seeland, and S. de Vries. 2005. Benefits and uses of urban forests and trees. In Urban Forests and Trees (pp. 81-114). Springer Berlin Heidelberg.

Ulrich, R. S. 1984. View through a window may influence recovery from surgery. Science 224:420-421.

U.S. Census Bureau. 2012. 2010 Census of population and housing: Summary population and housing characteristics. CPH- 1 - 37, Ohio U.S. Government Printing Office, Washington, DC. Retrieved 28 August 2016 from: https://www.census.gov/prod/cen2010/cph-1-37.pdf

USDA NRCS. 2016 The PLANTS Database. National Plant Data Team, Greensboro, NC 274014901 USA. Retrieved 24 August 2016 from: http://plants.usda.gov

Wolch, J. R., J. Byrne, and J. P. Newell. 2014. Urban green space, public health, and environmental justice: The challenge of making cities 'just green enough'. Landscape and Urban Planning 125:234-244.

Xiao, Q., and E. G. McPherson. 2002. Rainfall interception by Santa Monica's municipal urban forest. Urban Ecosystems 6:291-302.

Zipperer, W. C. 2002. Species composition and structure of regenerated and remnant forest patches within an urban landscape. Urban Ecosystems 6:271-290. 


\section{Figure Captions}

Figure 1. A typical A) inner-city vacant lot, B) inner-city residential lot, and C) suburban residential lot in Cuyahoga County, OH. Map shows the distribution of vacant land within the city of Cleveland, the eight inner-city neighborhoods (0-Broadway-Slavic Village, 1-BuckeyeWoodhill, 2-Central, 3-Detroit Shoreway, 4-Fairfax, 5-Glenville, 6-Hough, 7-Tremont), and the eight suburbs (shaded green). Figure adapted from Green et al. (2016).

Figure 2. Average tree abundance and taxonomic richness (A), native and exotic tree abundance (B), street tree abundance (C), and tree diversity (D) across inner-city (IC) vacant lots, inner-city residential lots, and suburban (S) residential lots in Cuyahoga County in 2015 ( \pm SE). Means with different letters of the same case (upper or lower) are significantly different $(\alpha<0.05)$.

Figure 3. Non-metric multidimensional scaling ordination of the community composition of trees on inner-city vacant lots (V), inner-city residential lots (I), and suburban residential lots (S) with $95 \%$ confidence limits. Stress of the final configuration was acceptable (0.18) and the ordination was plotted in three dimensions.

Figure 4. i-Tree Eco estimates of the percentage of trees within each stem diameter size class (DBH) measured at breast height (1.37 m above ground) on inner-city vacant lots, inner-city residential lots, and suburban residential lots in Cuyahoga County in $2015( \pm$ SE). Error bars are not included for the largest size class, which represents the sum of several size classes. 
Figure 1.

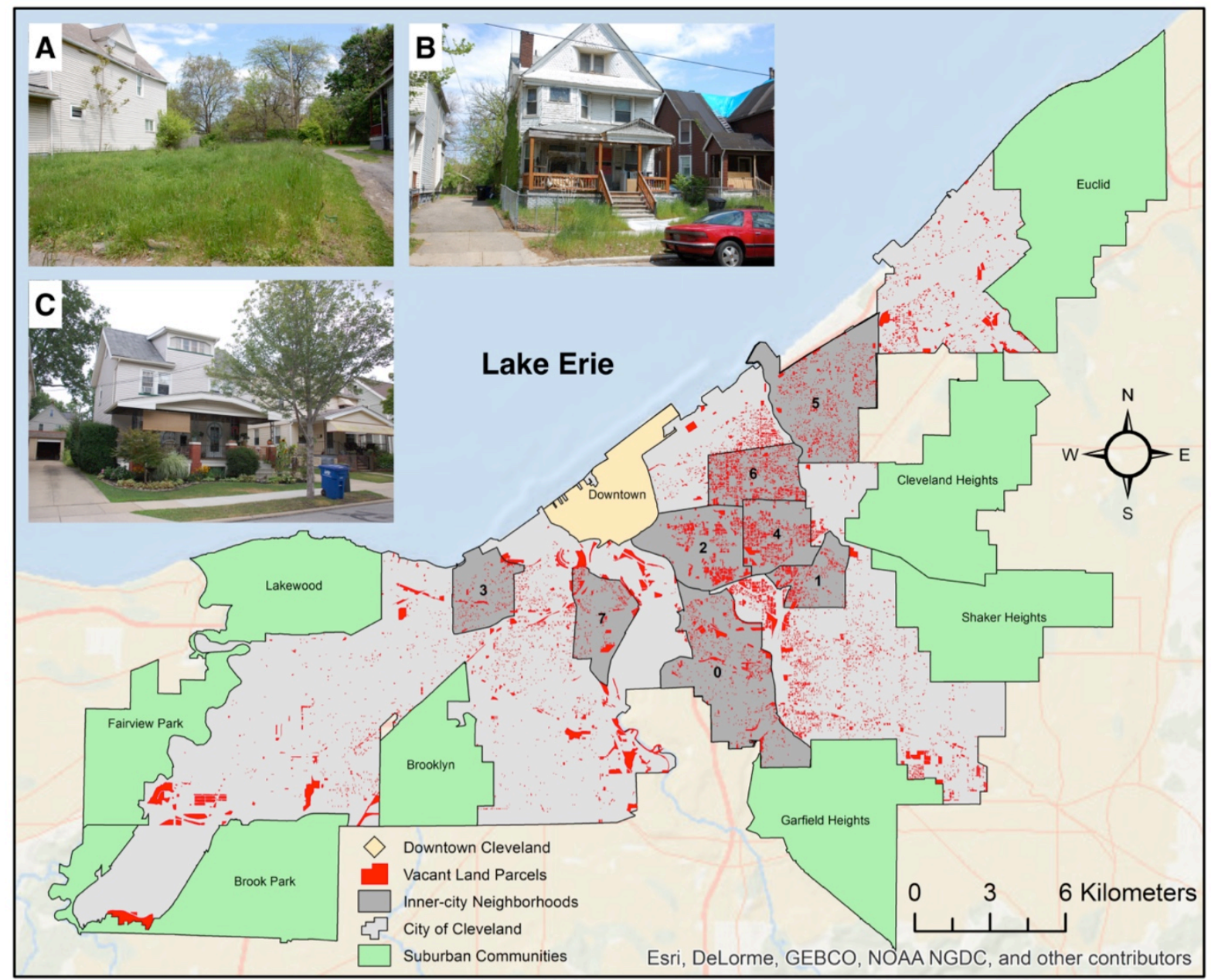


Figure 2.
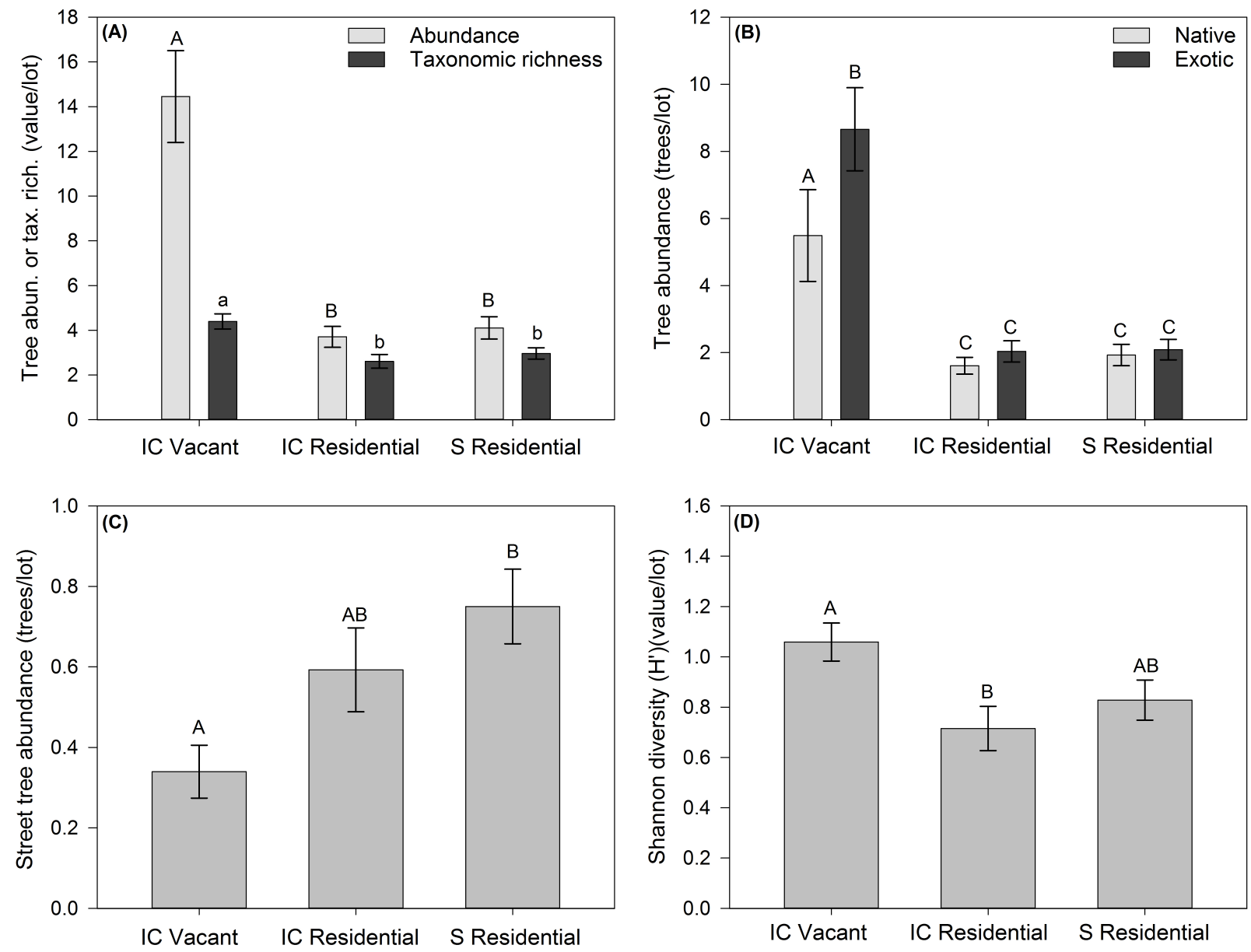
Figure 3.

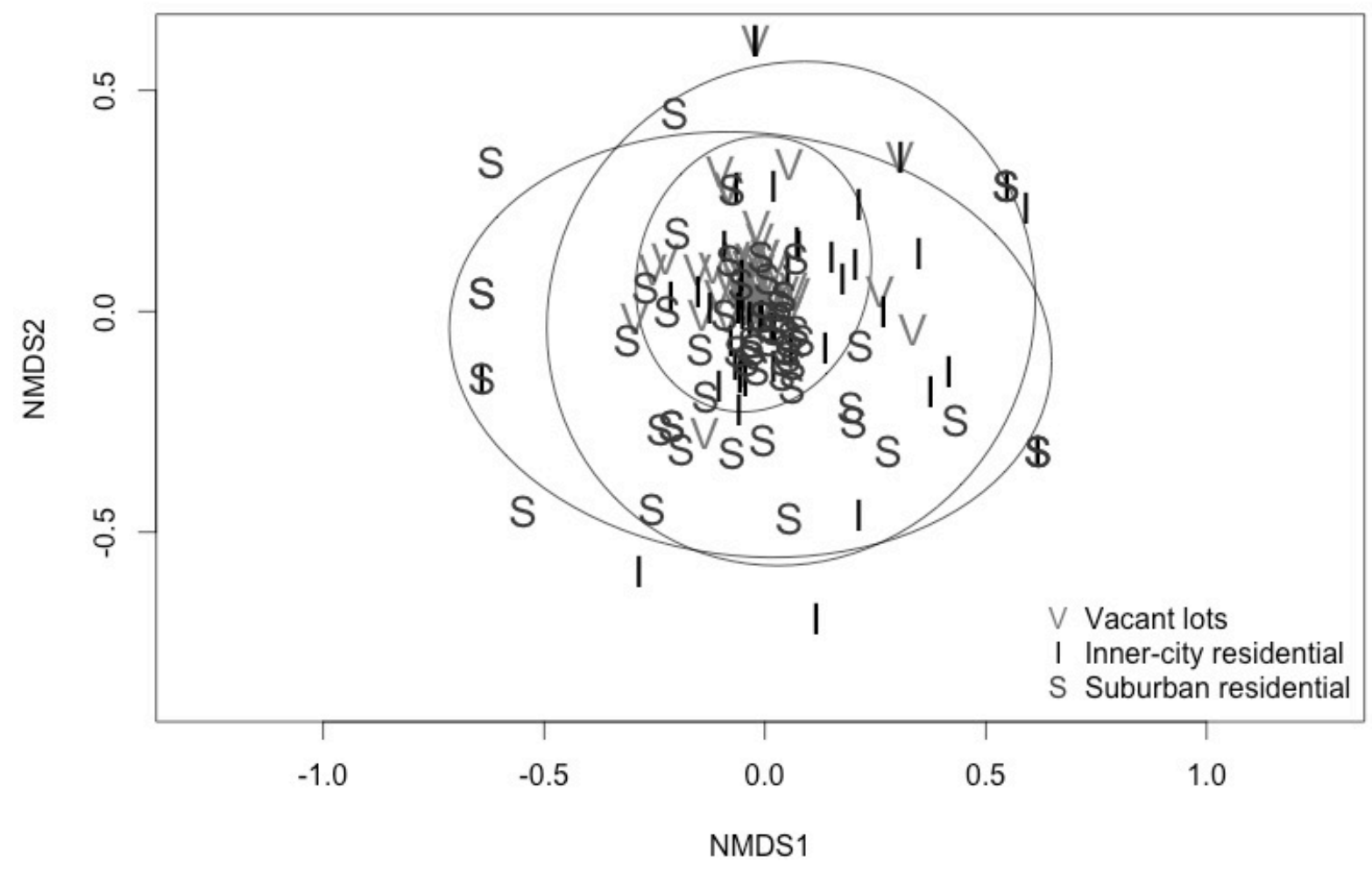


Figure 4.

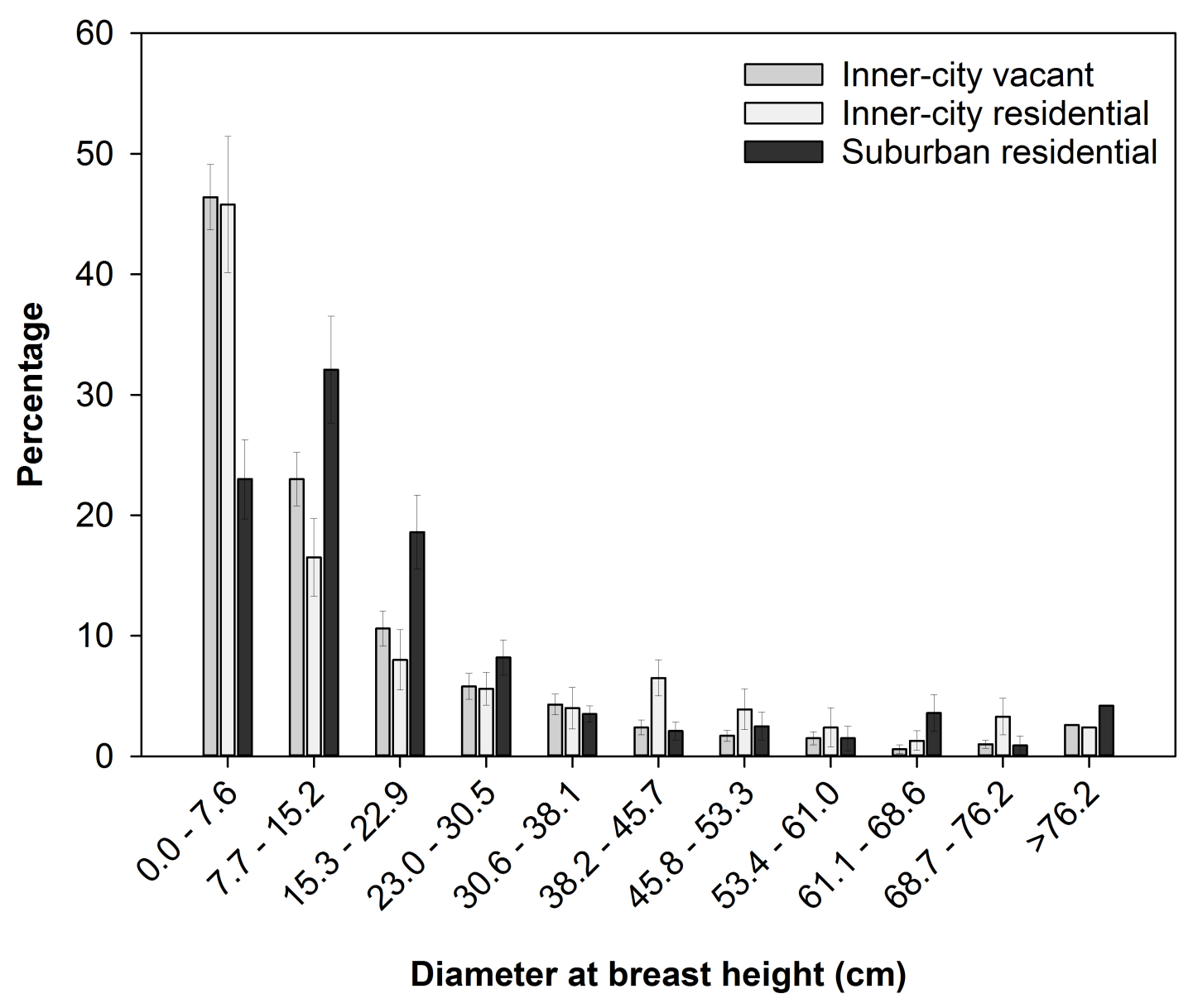


Table 1. Number of trees surveyed on 53 inner-city vacant lots, 54 inner-city residential lots, and 56 suburban residential lots in Cuyahoga County, OH during 2015.

\begin{tabular}{|c|c|c|c|c|c|}
\hline Genera & $\begin{array}{c}\text { Vacant } \\
\text { lots }\end{array}$ & $\begin{array}{l}\text { Inner-city } \\
\text { residential }\end{array}$ & $\begin{array}{l}\text { Suburban } \\
\text { residential }\end{array}$ & $\begin{array}{c}\text { Genera } \\
\text { totals }\end{array}$ & $\begin{array}{c}\text { Percentage } \\
\text { of total }\end{array}$ \\
\hline Abies & 0 & 0 & 1 & 1 & 0.1 \\
\hline Acer & 176 & 36 & 68 & 280 & 23.4 \\
\hline Aesculus & 1 & 1 & 0 & 2 & 0.2 \\
\hline Ailanthus & 49 & 16 & 0 & 65 & 5.4 \\
\hline Albizia & 0 & 1 & 0 & 1 & 0.1 \\
\hline Amelanchier & 0 & 0 & 2 & 2 & 0.2 \\
\hline Caragana & 0 & 1 & 0 & 1 & 0.1 \\
\hline Carpinus & 0 & 2 & 0 & 2 & 0.2 \\
\hline Carya & 6 & 0 & 1 & 7 & 0.6 \\
\hline Catalpa & 19 & 8 & 1 & 28 & 2.3 \\
\hline Celtis & 0 & 2 & 1 & 3 & 0.3 \\
\hline Cercis & 0 & 0 & 3 & 3 & 0.3 \\
\hline Chamaecyparis & 0 & 0 & 2 & 2 & 0.2 \\
\hline Cornus & 0 & 1 & 7 & 8 & 0.7 \\
\hline Crataegus & 7 & 2 & 0 & 9 & 0.8 \\
\hline Eugenia & 1 & 0 & 0 & 1 & 0.1 \\
\hline Frangula & 0 & 0 & 2 & 2 & 0.2 \\
\hline Fraxinus & 14 & 3 & 6 & 23 & 1.9 \\
\hline Ginkgo & 0 & 1 & 0 & 1 & 0.1 \\
\hline Gleditsia & 1 & 6 & 6 & 13 & 1.1 \\
\hline Ilex & 0 & 0 & 1 & 1 & 0.1 \\
\hline Juglans & 13 & 3 & 0 & 16 & 1.3 \\
\hline Juniperus & 0 & 2 & 0 & 2 & 0.2 \\
\hline Larix & 0 & 0 & 1 & 1 & 0.1 \\
\hline Liriodendron & 0 & 0 & 2 & 2 & 0.2 \\
\hline Magnolia & 0 & 2 & 1 & 3 & 0.3 \\
\hline Malus & 1 & 7 & 7 & 15 & 1.3 \\
\hline Morus & 196 & 38 & 20 & 254 & 21.2 \\
\hline Oxydendrum & 0 & 0 & 1 & 1 & 0.1 \\
\hline Phellodendron & 1 & 0 & 0 & 1 & 0.1 \\
\hline Picea & 1 & 2 & 7 & 10 & 0.8 \\
\hline Pinus & 0 & 2 & 4 & 6 & 0.5 \\
\hline Platanus & 6 & 1 & 0 & 7 & 0.6 \\
\hline Platycladus & 0 & 1 & 1 & 2 & 0.2 \\
\hline Populus & 2 & 2 & 0 & 4 & 0.3 \\
\hline Prunus & 31 & 12 & 8 & 51 & 4.3 \\
\hline Ptelea & 0 & 1 & 0 & 1 & 0.1 \\
\hline
\end{tabular}




\begin{tabular}{lccccc} 
Pyrus & 3 & 3 & 8 & 14 & 1.2 \\
Quercus & 10 & 10 & 8 & 28 & 2.3 \\
Rhamnus & 12 & 0 & 10 & 22 & 1.8 \\
Robinia & 10 & 4 & 0 & 14 & 1.2 \\
Salix & 0 & 1 & 2 & 3 & 0.3 \\
Sassafras & 1 & 0 & 0 & 1 & 0.1 \\
Sorbus & 0 & 0 & 1 & 1 & 0.1 \\
Taxus & 2 & 2 & 5 & 9 & 0.8 \\
Thuja & 0 & 13 & 25 & 38 & 3.2 \\
Tilia & 8 & 2 & 5 & 15 & 1.3 \\
Tsuga & 0 & 0 & 2 & 2 & 0.2 \\
Ulmus & 183 & 9 & 7 & 199 & 16.6 \\
Zelkova & 0 & 1 & 0 & 1 & 0.1 \\
Unknown & 12 & 2 & 4 & 18 & 1.5 \\
Total & & & & & 100 \\
\hline
\end{tabular}




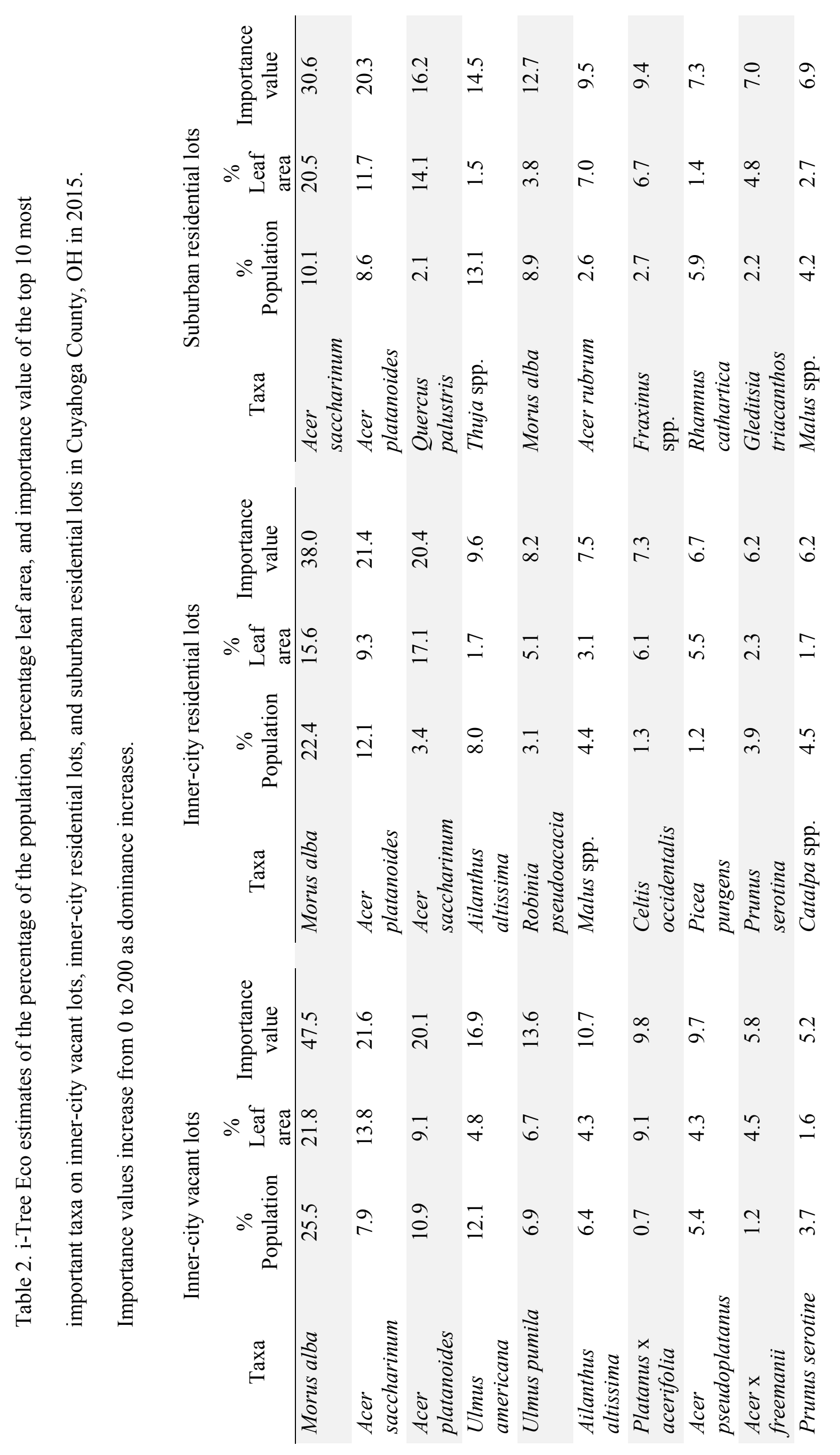



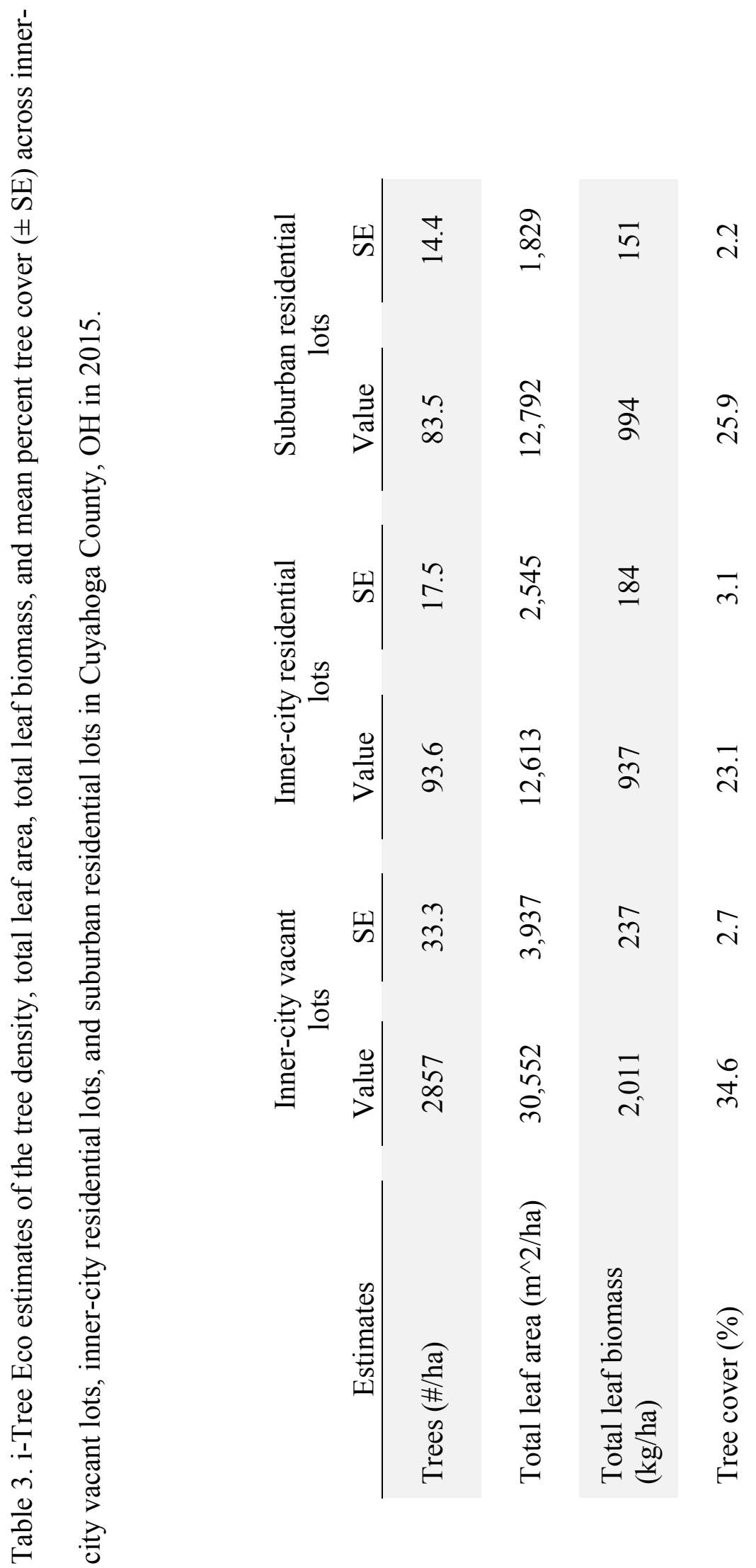

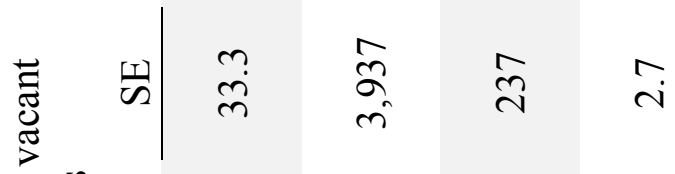

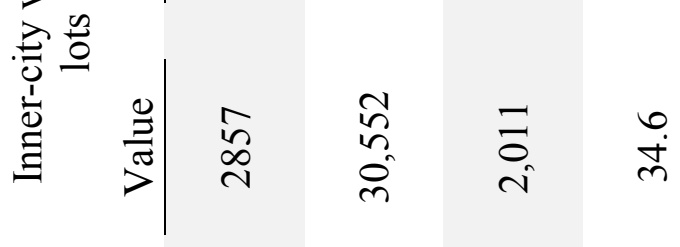

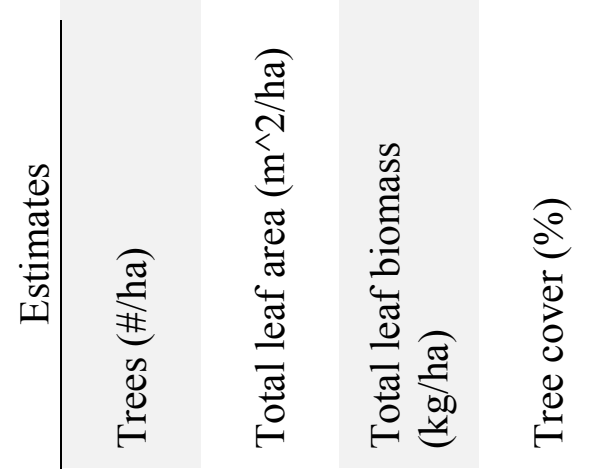


Table 4. i-Tree Eco estimates of the output of ecosystem services generated by a hectare of urban forest found on each property type in Cuyahoga County, OH in 2015.

\begin{tabular}{|c|c|c|c|c|}
\hline & Ecosystem services & $\begin{array}{l}\text { Inner- } \\
\text { city } \\
\text { vacant } \\
\text { lots }\end{array}$ & $\begin{array}{l}\text { Inner-city } \\
\text { residential } \\
\text { lots }\end{array}$ & $\begin{array}{c}\text { Suburban } \\
\text { residential } \\
\text { lots }\end{array}$ \\
\hline \multirow{3}{*}{$\begin{array}{l}\text { Energy } \\
\text { effects }\end{array}$} & British thermal units (MBTUs) & 36.9 & 7.0 & 4.3 \\
\hline & Megawatt-hours & 1.51 & 0.94 & 0.58 \\
\hline & Carbon avoided (kg) & 870 & 310 & 190 \\
\hline $\begin{array}{l}\text { mwater } \\
\text { inoff }\end{array}$ & Avoided runoff (m3/yr) & 63.0 & 37.1 & 40.3 \\
\hline
\end{tabular}

\begin{tabular}{|c|c|c|c|c|}
\hline & Carbon monoxide (kg/yr) & 0.54 & 0.36 & 0.41 \\
\hline & Nitrogen dioxide $(\mathrm{kg} / \mathrm{yr})$ & 5.3 & 2.9 & 3.2 \\
\hline \multirow{4}{*}{$\begin{array}{l}\text { Atmospheric } \\
\text { pollutant } \\
\text { removal }\end{array}$} & Ozone (kg/yr) & 16.5 & 9.7 & 10.7 \\
\hline & Particulate matter $10(\mathrm{~kg} / \mathrm{yr})$ & 14.3 & 7.2 & 7.7 \\
\hline & $\begin{array}{l}\text { Particulate matter } 2.5 \\
(\mathrm{~kg} / \mathrm{yr})\end{array}$ & 2.6 & 1.3 & 1.3 \\
\hline & Sulfur dioxide (kg/yr) & 4.6 & 2.7 & 3.0 \\
\hline \multirow{3}{*}{$\begin{array}{l}\text { Carbon and } \\
\text { oxygen } \\
\text { effects }\end{array}$} & $\begin{array}{l}\text { Carbon sequestration } \\
\text { density }(\mathrm{kg} / \mathrm{yr})\end{array}$ & 1483 & 672 & 566 \\
\hline & Carbon storage (kg) & 57,448 & 22,952 & 17,997 \\
\hline & $\begin{array}{l}\text { Oxygen production density } \\
(\mathrm{kg} / \mathrm{yr})\end{array}$ & 3,612 & 1,276 & 1,233 \\
\hline
\end{tabular}


Table 5. i-Tree Eco estimates of the monetary value of ecosystem services provided by a hectare of urban forest found on each property type in Cuyahoga County, OH in 2015.

\begin{tabular}{|c|c|c|c|c|}
\hline & Ecosystem services & $\begin{array}{l}\text { Inner-city } \\
\text { vacant lots }\end{array}$ & $\begin{array}{l}\text { Inner-city } \\
\text { residential lots }\end{array}$ & $\begin{array}{l}\text { Suburban } \\
\text { residential } \\
\text { lots }\end{array}$ \\
\hline \multirow{3}{*}{$\begin{array}{l}\text { Energy effects } \\
\text { (USD) }\end{array}$} & British thermal units (MBTUs) & $\$ 491$ & $\$ 93$ & $\$ 57$ \\
\hline & Megawatt-hours & $\$ 176$ & $\$ 110$ & $\$ 68$ \\
\hline & Carbon avoided & $\$ 128$ & $\$ 46$ & $\$ 27$ \\
\hline $\begin{array}{c}\text { Stormwater runoff } \\
\text { (USD) }\end{array}$ & Avoided runoff & $\$ 148$ & $\$ 87$ & $\$ 95$ \\
\hline \multirow{6}{*}{$\begin{array}{c}\text { Atmospheric } \\
\text { pollutant removal } \\
\text { (USD) }\end{array}$} & Carbon monoxide & $\$ 0.68$ & $\$ 0.45$ & $\$ 0.51$ \\
\hline & Nitrogen dioxide & $\$ 4.87$ & $\$ 2.68$ & $\$ 1.60$ \\
\hline & Ozone & $\$ 132$ & $\$ 79$ & $\$ 48$ \\
\hline & Particulate matter 10 & $\$ 887$ & $\$ 433$ & $\$ 280$ \\
\hline & Particulate matter 2.5 & $\$ 961$ & $\$ 469$ & $\$ 284$ \\
\hline & Sulfur dioxide & $\$ 2.09$ & $\$ 1.27$ & $\$ 0.78$ \\
\hline \multicolumn{2}{|c|}{ Value of ecosystem services (USD) } & $\$ 2,931$ & $\$ 1,320$ & $\$ 861$ \\
\hline
\end{tabular}

i-Tree Eco used the following monetary values: $\$ 13.32 / \mathrm{MBTU}, \$ 116.8 / \mathrm{MWH}, \$ 147 / \mathrm{mt}$ of C combustion avoided, $\$ 2.35 / \mathrm{m}^{3}$ of storm water runoff avoided, and $\$ 1,253 / \mathrm{mt}$ of CO removed.

Economic value of mean annual removal of the following pollutants was calculated based on these values for inner-city vacant lots, inner-city residential lots, suburban residential lots, respectively: $\$ 913, \$ 917$, and $\$ 505 / \mathrm{mt}$ of $\mathrm{NO}_{2} ; \$ 7,952, \$ 8,081$, and $\$ 4,463 / \mathrm{mt}$ of $\mathrm{O}_{3} ; \$ 61,908$, $\$ 60,265$, and $\$ 36,341$ / $\mathrm{mt}$ of PM10; $\$ 375,372, \$ 362,244$, and $\$ 211,626$ per / of PM2.5; and $\$ 458, \$ 462$, and $\$ 257 / \mathrm{mt}$ of $\mathrm{SO} 2$. 